\section{Gênero e identidade no futebol}

\author{
Gender and identity in football
}

O tema da seção Dossiê desta edição da revista FuLiA / UFMG

\section{é A PERFormatividADE do FUTEBol NA CULTURA: IDENTIDADE E}

GÊNERo, que propõe uma reflexão diversificada acerca da performance futebolística fora das quatro linhas em diálogo com o campo da linguagem e das ciências humanas.

Os artigos que compõem o dossiê resultaram do II Simpósio Internacional sobre Futebol, Linguagem, Artes, Cultura e Lazer, organizado pelo Grupo de Estudos sobre Futebol e Torcidas (GEFuT) e pelo Núcleo de Estudos sobre Futebol, Linguagem e Artes (FULIA), ambos da Universidade Federal de Minas Gerais, realizado entre os dias 08 e 10 de setembro de 2016, em Belo Horizonte, na Escola de Educação Física, Fisioterapia e Terapia Ocupacional (EEFFTO) da UFMG e no Museu do Mineirão.
O dossiê aqui apresentado foi motivado pela temática predominante dos artigos selecionados para publicação, que abordaram predominantemente questões relacionadas ao gênero e à identidade.

Contamos com artigos provenientes das áreas de Letras, Antropologia, Comunicação, História e Ciências Sociais, submetidos por pesquisadores brasileiros e argentinos, o que demonstra a importância da revista para promoção do intercâmbio das produções acerca dos estudos futebolísticos na América Latina.

Nicolás Cabrera (Universidad Nacional de Córdoba) propõe em "Las resonancias del pasado: apuntes para un estudio diacrónico y sincrónico de una hinchada del fútbol argentino" uma abordagem antropológica para dar conta do fenômeno das torcidas organizadas - "barras bravas". Para o autor, o tema é central nas narrativas acerca do futebol contemporâneo.

Já em "Marta em notícia: a (in)visibilidade do futebol feminino no Brasil", de Soraya Barreto (UFPE), é apresentada 
uma análise da cobertura realizada pelos portais de notícias pernambucanos sobre a Copa do Mundo de Futebol Feminino 2015 e, especialmente, sobre a jogadora Marta. Como resultado, percebe-se o predomínio de discursos que obedece aos padrões do senso comum e contribui para a permanência de estereótipos e silencia-mentos acerca da mulher e do futebol feminino.

Por sua vez, Marcus Vinícius Costa Lage (UFMG) analisa as representações do América Futebol Clube de Belo Horizonte veiculadas pela revista América: a voz dos americanos, editada na capital mineira entre 1947 e 1950. Por meio de uma pergunta inicial já contemplada no título, "Revista América: a voz dos americanos"?, o autor demonstra o impacto do discurso do periódico ao enquadrar assuntos políticos do clube na cobertura futebolística, considerando a "perspectiva do lucro e do mercado editorial".

Em “Se vencer o Palestra, vence a 'bella' e legendária pátria italiana: um estudo comparado dos Palestras Itália de São
Paulo e de Belo Horizonte (1914-1933)”, Rodrigo Caldeira Bagni Moura (Universidade Salgado de Oliveira) contribui com uma análise comparativa entre o Palmeiras (1914) e o Cruzeiro (1921), com o objetivo central de apontar para o processo de afirmação dos dois times, "buscando compreender qual a importância do futebol no processo de inserção e pertencimento dos italianos nas duas capitais mencionadas e qual a contribuição dos Palestras para sedimentar a noção de identidade italiana entre os membros da colônia".

Gustavo Andrada Bandeira (UFRGS) e Maria Nemesia Hijós (Universidad de Buenos Aires), em "Significados das emoções no futebol brasileiro e argentino: um diálogo em contextos etnográficos distintos", procuram interpretar de que modo emoções e sentimentos são entendidos para a construção de masculinidades ou para as narrativas comercias do 'produto futebol' narradas e representadas em dois contextos etnográficos distintos, Porto Alegre, Brasil, e Buenos Aires, na Argentina. 
Fechando o dossiê, contamos com o estudo intitulado “Translações no Facebook: a controvérsia "Galo Machista”!? nas páginas de torcidas organizadas", de Carlos d'Andréa, Leonardo Melgaço e Roberta Firmino (UFMG), que contribui para as reflexões sobre a controvérsia em torno da exploração do corpo feminino e do machismo no futebol desencadeada pelo desfile de lançamento do novo uniforme do Clube Atlético Mineiro, em fevereiro de 2016. Os discursos selecionados foram enunciados por torcedores nas páginas do Facebook de cinco torcidas organizadas do time.

Por sua vez, a seção Paralelas conta com o artigo intitulado “O futebol filmado: Tostão, a Fera de Ouro (1970)", de Luiz Carlos Ribeiro de Sant'Ana (Fundação de Apoio à Escola Técnica do Estado do Rio de Janeiro), que tece considerações específicas sobre o documentário Tostão, $a$ fera de ouro, dirigido por Paulo Laender e Ricardo Gomes Leite. Esse texto é significativo na medida em que procura "circunscrever a produção da obra aos seus aspectos conjunturais mais gerais e no âmbito da feitura de películas sobre futebol até aquele momento".
Por fim, a seção Poética conta com a reescrita da narrativa de minha autoria, "El Minero nas Ilhas GALÓPAGos", derivada da série intitulada "El Minero: o atleticano, enfim, conhece a América Latina", publicada no Ludopédio.

Desejo a todos uma boa leitura!
Gustavo Cerqueira Guimarães Pesquisador da Faculdade de Letras da UFMG (PNPD-Capes), membro do FULIA e coeditor da revista FULiA / UFMG 